\title{
The Unicorn in the Symbolic and Semantic Expression of the Film Director Ridley Scott in the Context of Medieval Bestiaries
}

\author{
Vanda Babić, Denis Vekić \\ University of Zadar, Zadar, Croatia \\ Email:vbg109@gmail.com, dvekic5@gmail.com
}

How to cite this paper: Babić, V. and Vekić, D. (2018) The Unicorn in the Symbolic and Semantic Expression of the Film Director Ridley Scott in the Context of Medieval Bestiaries. Open Journal of Social Sciences, 6, 158-175.

https://doi.org/10.4236/jss.2018.62014

Received: January 29, 2018

Accepted: February 24, 2018

Published: February 27, 2018

Copyright $(9) 2018$ by authors and Scientific Research Publishing Inc. This work is licensed under the Creative Commons Attribution International License (CC BY 4.0).

http://creativecommons.org/licenses/by/4.0/

(c) () Open Access

\begin{abstract}
This paper observes and researches the relations between symbolic unicorn representation in Ridley Scott's movies Blade Runner and Legend comparing it to the medieval bestiary descriptions and representations. The goal in this research is to determine is Scott's imagery different from the medieval one and authors tend to research and compare that relation in this analysis. In the art of film, the unicorn most often makes its appearance as an objectively presented mythic animal, and, as such, represents the specific symbols with which it is attributed. The English film director Ridley Scott uses the motif of the Unicorn in order to expand semantic value. Scott's cinema unicorns are very similar to those in medieval bestiaries and representations, yet there are nuances in meaning which propose the specifics of this unicorn motif in contemporary representation in relation to medieval bestiaries. In the film Blade Runner (1982), the explicit symbolic and metaphorical value of the unicorn can be observed, and this can also be found (in an even more intense form) in the film Legend (1985) in which the semantic component is clearly defined by medieval bestiaries and medieval representations. The director's relationship towards this mythic animal is a reflection of his artistic approach to film, which will be investigated here in the context of the author's specifics within the film industry.
\end{abstract}

\section{Keywords}

Unicorn, Ridley Scott, Symbol, Medieval Bestiary, Blade Runner, Legend 
Rachael: Do you like our owl?

Deckard: It's artificial?

Rachael: Of course it is.

Deckard: Must be expensive!

Rachael: Very.

Blade Runner, 1982.

\section{Introduction}

Medieval bestiaries and their contents were once of great interest to geographers, priests, scientists, researchers, biologists, but also to the common people who transferred and expanded the descriptions of various mythic animals in oral traditions as part of folkloric memory and its specifics. The meaning which these mythic animals once had developed over time, and their motifs have been preserved up to today's day and age: such motifs have assumed new roles and meanings in contemporary media. The convergence between the medieval and contemporary motifs of the mythic unicorn was made ostensible in the films Blade Runner and Legend by the English film director Ridley Scott. Is there a reason why the unicorn, as a mythic animal appeared in both films? It is also very important to note that the two films are only related as they were directed by the same man. Furthermore, why is the unicorn significant for both films? The answer can be found by analysing what the symbol and motif of the unicorn (as a mythic animal in medieval bestiaries) offer in Scott's interpretation of their meaning.

When researching certain motifs in the art of film, it is necessary to take into account how the director creates and distributes them. The role and meaning of motifs in film are derived from the infinite spectrum of the nuances of experience in the life of man. Despite whether or not one is dealing with motifs or symbols which represent motifs, in the final products of the art of film there is a great oversaturation of motif and symbol still awaiting recognition and an adequate application in the research of the kind of artistic expression which is film. Film in theory, in its widest sense is seen as a language and audio-visual communication, based upon the foundations which apply to language as a system. Film is a communication system as language is. The common aim of these communication systems is that they allow the conclusion that film (like language) transmits thoughts [1].

The feature film is an artistic medium which, besides entertainment, fulfils several additional functions, some of which are pedagogical, psychological and sociological. Film communicates at five levels, i.e. in five communication systems: in images, in speech, sound, music and (with certain reservations) in letters ([1] p. 24). In motion pictures, all has been determined beforehand and carefully planned, with the position of the viewer determined as well. The viewer, he/she watching the motion picture is a passive observer, and such a position determines not only the relationship towards what is seen, but also the relationship towards the viewer [2]. The messages transmitted by a motion picture 
can be various and polysemic. As projection takes place in the dark and the gaze is drawn to only one direction, the viewer can feel as a loner in a society and comprehend the message personally. It is in this sense that the projection represents something unique and often has a para-hypnotic effect on the viewer as a result [1]. The easily attainable effects of film can increase the qualities of its similarity and recognition as in the decoding of proposed symbols [1]. When one is dealing with the director and producer Ridley Scott's feature films, messages, the symbols and motifs which are proposed to recipients possess the message and meaning which the director had intended. This conclusion will be made more ostensible in our analysis of these films. Ridley Scott is an English film director and producer born in Durham in 1937. He has gained fame in the art of film with titles such as Alien, Blade Runner, Gladiator, Black Hawk Down, Kingdom of Heaven, et al. Although his most important films were not great successes at the box office, they went on to become cult classics and eventually recognised as key representatives of the Science Fiction genre [3].

Scott has become known as a reviser of his own films and has also become known thanks to his director's cuts which are often stylistically better and with better plot lines than their original cinematic releases. The films Blade Runner and Legend are significant for this analysis due to fact that both films offer a representation of the mythic animal of the unicorn.

This analysis offers new views on the research of the symbolic and semantic functions of mythic animals in the art of film, especially in the two aforementioned films by this acclaimed director. The reasons for the selection of this topic lie in the fact that this film director and producer has used the same mythic animal twice in his film-making career and all its additional symbols and attributes, so that by mitigating them he could transmit a message to his viewers who were to accept it in the process of decoding the motifs and symbols which Ridley Scott has sent them. Certainly, viewers as recipients, in order to comprehend the message, must understand the meaning of the symbol which the director has presented. What is to be understood by this is the recognition of the certain symbols and meanings which have attributed to the unicorn which viewers have preserved for centuries in legend and folktale, and which have been shaped through the motif spectrum of medieval bestiaries. It is exactly in this analysis that the similarities and differences of the motif of the unicorn in film in the work of Ridley Scott and of this motif in medieval bestiaries will be researched at the symbolic and semantic levels. In this instance we will not be dealing with reports and descriptions of the unicorn from Classical Antiquity to the Modern Age, as wide-ranging studies have been written on this topic by authors who have exhaustively presented a chronology of the visualisation of the unicorn. ${ }^{1} \mathrm{~A}$ quality presentation of the visualisation of the unicorn has been offered by Chris Lavers [4] and Richard Ettinghausen [5] in their works The Natural History of Unicorn and The Unicorn. It is important to not at the beginning of our work that the two films under analysis here belong to completely different film genres. The first film, Blade Runner, had its premiere on the $26^{\text {th }}$ of June 1982 and be- 
longs to the genre of Science Fiction and is considered a classic of this genre, but also as one of its examples by widening its subgenre structure toward a dystopian cyberpunk and toward Science Fiction noir (Internet Movie Database $\mathrm{IMDb}$ ). The films screenplay originated as a rather free interpretation of a story from the novel Do Androids Dream of Electric Sheep? (1968) by Philip K. Dick. The second film, Legend, had its premiere on the $18^{\text {th }}$ of April 1986, and yet in film archives the year of its making is noted as 1985. In structure the film Legenda is a typical fantasy film. Its plot, characters, place and time of action place this film on the narrow genre boundary between fable and fantasy. And yet, despite such narrow genre affinity, certain mythic symbols with origins which can be clearly found in Christianity can be observed.

\section{Blade Runner and the Motif of the Unicorn}

In this film the unicorn makes its appearance in two brief scenes, yet it has a very important meaning for an understanding of the film. The main protagonist of this film, the policeman Deckard, is actually a replicant and this is fact which remains unknown until the last few seconds of the film when this is confirmed by the motif of the unicorn itself. The unicorn makes its first appearance in the $42^{\text {nd }}$ minute of the film, when Deckard finds himself fatigued and inebriated and almost falls asleep over the piano. In his half-sleep/vision he sees a unicorn running towards him in a forest (Blade Runner, 1982.). The unicorn is presented as a powerful white horse with a spiral-shaped horn in the middle of its forehead. Its horn is almost identical to that of a narwhale's. ${ }^{2}$ Only the visual motifs of the unicorn could be detected in this brief scene, yet the wider meaning of this motif could not, including the medieval motif of the lady with the mirror and hunters

\footnotetext{
${ }^{1}$ Videlicet: Beer, Rüdiger, Robert. 1977. Unicorn: Myth and Reality. Mason/Charter, New York; Giblin, James i McDermott, Michael. 1991. The Truth about Unicorns. Harper Collins Publishers, New York; Goldsmid, Edmund; Grube, Herman; Kirchmayer, Georg Kasper; Schoock, Martinus. 1886. Un-Natural History, or Myths of Ancient Science. Privately printed, Edinburgh.

https://archive.org/details/unnaturalhistory01golduoft (accessed 8. 1. 2014); Gotfredsen, Lise. 1999. The Unicorn. Abbeville Press, New York; Freeman, Margaret Beam. 1974. The Unicorn Tapestries, Metropolitan Museum of Art, New York; Slifkin, Nathan Rabbi. 2007. Sacred Monsters: Mysterious and Mythical Creatures of Scripture, Talmud and Midrash. Zoo Torah, Brooklyn, Jerusalem. http://books.google.hr/books?id=_1fdxxS26RYC\&printsec=frontcover\&dq=Sacred+Monsters: + Myst erious+and+Mythical+Creatures+of+Scripture, + Talmud + and + Midrash\&hl=hr\&sa $=$ X\&ei=3EdBU8 -JAYGqyAOj_YDIBA\&ved=0CC4Q6AEwAA\#v=onepage\&q=Sacred\%20Monsters\%3A\%20Mysteri ous\%20and\%20Mythical\%20Creatures\%20of\%20Scripture\%2C\%20Talmud\%20and\%20Midrash \&f= false (accessed 21. 2. 2014.); Cavallo, Adolph S, ur. 1998. The Unicorn Tapestries at the Metropolitan Museum of Art. Harry N. Abrams, Inc., Metropolitan Museum of Art, New York.

http://books.google.hr/books?id=JrWh6I3JQgIC\&pg=PA128\&dq=The+oak+king,+the+holly+king, +and+the+unicorn:+the+myths+and+symbolism+of+the+unicorn+tapestries\&hl=hr\&sa=X\&ei=A0 hBU_LzC4O_ygOckYGICw\&ved=0CDMQ6AEwAQ\#v=onepage\&q=The\%20oak\%20king\%2C\%20t he\%20holly\%20king\%2C\%20and\%20the\%20unicorn\%3A\%20the\%20myths\%20and\%20symbolism\% 20of\%20the\%20unicorn\%20tapestries\&f=false (accessed 7. 12. 2013.)

${ }^{2}$ The narwhale, (Monodon monoceros), is a sea mammal of the white whale species (Monodontidae). It lives in pods in the Arctic seas. In the past it was believed that a narwhale's horn was that of the unicorn. Its horn can grow up to three meters in length and is actually the incisor if its upper jaw. The horn is most often white and spiral in shape. http://proleksis.lzmk.hr/38467/ (accessed 15. 12. 2013.)
} 
who would kill it. The unicorn is the only mythic animal in this film. All other mechanical or real animals are part of the real world. As the unicorn in this film is presented as white horse powerful and beautiful in its form, it can be said that the director's representation of it follows the classic type. This more classic type of unicorn spread in the middle ages due to heraldry [6], especially as it was on the emblems on both the kingdoms of Scotland and England. The unicorn is presented on heraldic emblems as a rare and beautiful animal in the form of a white horse with a spinal horn in the middle of its forehead [7]. In heraldry the unicorn is often compared to a horse, and the constructions of these descriptions are often state as a horse [7]. Meanwhile, it is not only in medieval bestiaries in which the unicorn is described in this way: it was also in the medieval Islamic imaginarium that descriptions of the unicorn were compared to that of other animals ([5] p. 13). And yet, Scott had decided on the heraldic version of the unicorn, cleansing its image to the extent that unicorn was a horse with horn in the middle of its forehead. The motive for this extremely simplified version of the visualisation of the unicorn was probably the financial nature of making this film. As Scott was already finalising the preparations for his next film (Legend) while completing the making of Blade Runner, he used the trail scenes from the new film in Blade Runner. He used two film sets in this way without having to resort to either animation or digital images. What increased the costs of making Legend was an unfortunate accident on set: while filming the set was caught by fire which caused an increase in costs. Blade Runner's poor results at the box-office only made the situation worse.

When designing the interiors in which the scenes in his films take place, Scott especially takes care of details which can analysed and interpreted through repeated viewings. Such is the scene in which the unicorn appears: only a few seconds earlier, in the background of this shot the figure of a unicorn can be seen serving as a paperweight on a small pile of papers. As many of the descriptions of the unicorn in antiquity, the early middle ages in Europe and the far East were similar to descriptions of the rhinoceros, it can be assumed that the director, by using subliminal messages intensifies context of the symbols in the film. Tony Scott, Ridley's brother, stated that there is Ridley in every segment of the film [8]. It is interesting that the scene with the unicorn was added to the film Blade Runner from another project that Ridley Scott was working on at the time. The scene with the unicorn was included in the system of symbols of origami figures because Scott had recorded the scene with the unicorn on film, a scene which was actually intended as part of the film Legend [8]. The unicorn appears for the second time in the last few seconds of the film, and that in the form of an origami unicorn. Thus, it appears with a symbolic meaning as an explanation and conclusion of the reason why the unicorn appeared the first time. Gaff, the policeman overseeing Deckard's police duty, leaves origami figures throughout the film which symbolise Deckard's decisions and desires at the time. It is thus that the first origami figure is that of a chicken, symbolising Deckard's cowardice when refusing the case involving the hunting of replicants. Following the 
chicken, the next origami figure is that of a man with an erection, symbolising Deckard's desire for the replicant Rachel. The third origami figure is that of a unicorn and it does not describe Deckard's decisions. And yet, the origami unicorn symbolises a small segment of his life when he dreamed of a unicorn. As Gaff was one of the internal controls in law enforcement, the director, by using the origami unicorn, provided the audience with the message that Deckard is a replicant and that his memories have been implanted and that information on these implants can be found in his dossier. Gaff read his dossier and knew from the beginning that Deckard was a replicant so that with his final act-an origami unicorn and letting Deckard go free-he informed him that he had read his dossier and uncovered a personal secret which could radically change his life. In an interview, Ridley Scott had the following to say on this:

And that was only reference right there to this abstract image which is unicorn. "Cause in the end it comes out of his thought process. That never occurs again" till the end of the movie. "Cause, when he comes to his apartment he thinks that he's (Gaff) got there and killed her", cause they know where she is. And when they come out, there it is unicorn. Interviewer: And it means?

Scott: He is a replicant [9].

Meanwhile, the director, using contemporary symbols of the unicorn, extends the message from the basic association of this motif to the level of a concept. In the context of Deckard's daydreams, the unicorn inherits the meaning of something incomprehensible, unattainable, something that does not exist in the real world, unreal and fantastical. As the film is based on the proposition that replicants seek a longer life than the four years allotted them, they have taken a journey (in the plot of this film) in order to extend their life-span, which is for them, in the end, unattainable. The director implies in this way that the unicorn was a mythic animal which was difficult to catch; this coincides with the medieval idea that the unicorn was difficult to catch without the aid of a virgin which would distract its attention.

The motive for using the unicorn as a mythic animal in the film Blade Runner still remains unclear as the director did not disclose the reasons why he had used that animal in particular. And yet, the symbolic value of the unicorn in this film has almost attained an iconic meaning in which the origami unicorn represents freedom. After Blade Runner, the motif of the origami unicorn had almost become the symbol of the film itself in the wider culture of cinema, but also the central idea of the film in which the fantastic element of the thought-process can become a part of the transformation of a replicant in a human being. In this way the unicorn has become the totemic animal of the replicant Deckard and also symbolises his relationship towards Rachel. As Rachel is a replicant, her existence is a pragmatic one and lacking in many truly human characteristics. Although she has lived a human life, Rachael (as a personage) has not experienced many of the elements of an emotional relationship, so that she has been deprived of the emotions of having fallen in love, love itself, sadness, happiness, hope etc. Throughout the film, Rachael can be perceived as a untainted as the elements of 
her character have not been sullied by acts of evil, guilt and other negative aspects. Certainly, as she has absolutely no sexual experience, Rachel is (regarding motif) a virgin. As Gaff had followed Deckard and inspected his work, it can be stated that he was in a specific "hunt" after his "error". Once the "error" has been disclosed (Deckard realises he is a replicant), Gaff decides to let him go free. Observing this in a wider metaphorical and symbolic sense, Deckard can be seen as a unicorn which has been drawn to a virginal maid. The affirmations for such a perception as this are few and can only be determined via the Gaff-Deckard-Rachael relationship.

\section{Other Animals in Blade Runner and Their Symbolic Meaning and Relevance Following the Unicorn}

The animals which appear visually in the film Blade Runner are not, for the most part, biological in origin. They are mostly mechanical and because of this are quite expensive. The first animal that appears in this film is an owl found in Eldon Tyrell's building (the wealthiest man in the world), in which some of the action in the film takes place. In ancient Greece the owl was a symbol of wisdom and of dreams [10], ([6] p. 444). Tyrell is the inventor and producer of replicants (which have been produced in several generations), while the latest generation is so advanced that the replicants themselves do not know they are replicants, but believe themselves to be humans. The primary foundation of this belief is memory, but these have been implanted, which means that disclosure can occur when a replicant faces this fact. The owl found in the rooms of Tyrell's home/corporation transmits the function of its semantic symbols to Rachel, a replicant which becomes aware of this fact only when it is faced with the knowledge that its memories are implants. The director connects animals in this film to certain characters, so that certain animals become totems of the characters to which they have been attributed [11]. The motifs and symbols which the animal represents in the film are transferred to the characters connected to them. Besides the owl, there are two figures of the eagle in the same room symbolising power, and both are placed on the utmost height of two obelisks, representing the power of Tyrell's corporation.

Other animals which appear in the film are a snake, spider, pigeon, an origami chicken and wolf, yet only with a totemic meaning. The snake in this film is a mechanical one and is used as an attribute for the character Salome, who earns her pay as an exotic dancer with a snake in a seedy night-club. Thy symbol of Salome and snake together, as well as the circumstance in which they appear, are markers of the Old Testament allegory of Evil (which had taken the form of a snake). The basic symbol of Salome is the following: living a life of promiscuity and dancing with a snake, Salome symbolises the sin of lust when the club's host announces her to the guests:

Ladies and gentlemen! Taffey Lewis presents Miss Salome and the snake. Watch her take the pleasures from the serpent that once corrupted man. (Blade Runner, 1982) 
The pigeon which Roby Batty holds in his hands becomes a symbol of his soul flying off to heaven at the moment of his. Besides this, Batty, in his hunter after police officer Deckard, howls like a wolf on one occasion, in this way taking on the role of a hunter after his prey. By doing so, Batty his attributed to himself the totem of a hunting wolf.

\section{The Film Legend or the World of the Last Unicorn}

As the film Legend was conceived as a motion picture fable replete with classic fairy-tale motifs, the director Ridley Scott defined the film as a continuation of the traditions and conventions of fable: This is a fully in tradition, you know, of a "Night on a Bare Mountain", or "Night on a Bald Mountain", "Mirror Mirror on the Wall", you know "who is the most beautiful of them all" [12]. Although the selection of the unicorn as a mythic animal is not explained explicitly in this film, its section can be interpreted according to the traditions of the classic elements of fable: other lower mythical beings are in this film, some them even of demonic origin. Other than the unicorn, there is also a goblin in the film, a dwarf, a half-mechanical demon, a devil named Darkness, a forest fairy (dryad), a swamp witch, gnomes, winged demons, sin/demon and others. The world of the film Legend is deeply divided between the forces of good and the forces of evil (as is almost always the. Its topos and the time frame of its action are undefined, so that it can be stated that the director's procedure here is also to define the film as a fable. Besides this polarity of division between good and evil, the unicorn (as a locus classicus) is beyond the categories of good and evil, becoming the supreme being of good in the entire world of the film. In this film, the character Jack describes unicorns in the following way: "Nothing is more magical. As long they roam earth, nothing can harm the pure of heart. (...) They express only love and laughter. Dark thoughts are unknown to them" (Legend, 1985). In folkloric legend, medieval unicorns are also symbols of power, good fortune and purity [13]. Only two unicorns appear in the film, and this in the form of two strong white horses with spiral-shaped and glowing white horns in the middle of their foreheads. It is clear that the perception of the unicorn in Legend is not different to the one in the film Blade Runner. The appearance of the unicorn in this film is almost identical to the visual scheme of the unicorn on the $15^{\text {th }}$ century tapestry La Dame à la licorne which was found in the Château de Boussac and was once in the possession of the Le Viste family, and is now curated in the Musée du Moyen-Age museum in Paris. ${ }^{3}$ In order that the scheme of the legacy and legend of the unicorn are complete, the director placed the context of the Unicorn in the context of the entire story. Besides the detail of the unicorns playing alongside a forest spring (evidence that the director clearly has knowledge of the legends and symbols surrounding the unicorn), there are also clear connections between these unicorns and the virgin in this film ([6] p. 584).

${ }^{3}$ More detailed information on a series of tapestries can be found on the web pages of the museum which curates them:

http://www.musee-moyenage.fr/collection/oeuvre/la-dame-a-la-licorne.html 
The main characters in this film are Lili and Jack, while their adversary is also the adversary of the whole world-Darkness, a character whose physical attributes are something of a combination of devil and satyr. Jack is a young adventurer whose characteristics are typical of fable. He is a youth living on the forest (which also provides his sustenance) and who falls in love with, a princess visiting the forest. His adventurous and impulsive spirit is a common characteristic of fairy-tale heroes who are to face obstacles which they are to overcome with skill, cunning, goodness and strength. Lili is presented in the first half of the film as an entirely morally pure maid with oblivious to the troubles of this world and whose spirit is entirely without blemish. The basic motifs which are her attributes are also to be found in fable and are made manifest on her relationship toward nature and toward Jack. Her symbolic function is elevated to new level of motif which is also part of the attributes of legend. When Jack decides to show her the unicorns, her role gains a new dimension and she becomes the virgin from the legend of the virgin and the unicorn. The multiplication of motifs here occurs on more levels.

Early in the film it is clear that Lili is a virgin and that she is uncorrupted by evil. Her very name implies purity and the whiteness of the flower of the same name (a classic motif): as one can find in Christian symbolism, there are examples in which the lily symbolises virtue, purity and virginity. In iconography, the archangel Gabriel makes his annunciation to the Virgin Mary with a lily in his hands, and here the lily represents Mary's virginity. Lili has no divine attributes in this film, but there is evident symbolism which presents her as a virgin undefiled by sin and the sexual act. A confirmation of this symbolism is the following: in the scene in which Lili first sees the unicorns at play, Jack picks a lily for her, which is certainly not a coincidence.

The second multiplication of the motif concerning a female character occurs when Lili decides to approach the unicorns which had not noticed her until that moment. As lily and Jack did not know at that moment that they were being spied upon by the servants of evil who were in fact hunting unicorns, Lili approaches the unicorns which widens a perspective of which she is not aware: at the very beginning of the film, Darkness, the main adversary, devil and ruler of darkness, orders his servants to procure a unicorn's horn so that he can rule in darkness. In order to catch a unicorn, his servants require the bait which can placate it, and according to the master's order this can only virginity can do this:

Darkness. There is only one lure for such disgusting goodness, one bait that never fails.

Blix: What be this bait? Please, you teach me!

Darkness: Innocence. Innocence! (Legend, 1985)

There are various sources which mention the basic element that a virgin's virginity as the only thing that can attract a unicorn [14]. In the very moment when Lili makes contact with one of the unicorns, Blix-a servant of evil, shoots a poison arrow and kills one of them. He removes its horn and keeps it for himself as it has been confirmed that it has magical powers, yet it does not have the 
power to heal as the legends claim. Alicorn, the unicorn's horn possesses healing properties according to legend and fable. According to a legend from the $11^{\text {th }}$ century, he who drinks from the horn of a unicorn will be protected from all poison [15]. The unicorn's horn in this film is presented as a magical object which, depending on who is holding it in his/her hands, can perform acts of magic. At the end of the film, the powers of alicorn are multiplied when they are used to exterminate the incarnation of evil-Darkness.

The symbols which are attributed to the unicorn in this film totally correspond to the motifs the unicorn possesses in legend. In this film, the unicorn is a symbol of purity and innocence. Besides this, the unicorn is drawn by feminine virginity and purity which is characteristic of unicorns in legend [14]. The symbolical level of the unicorn in this film is amplified by the fact that one of two unicorns has been killed so that only one unicorn remains in this world, which makes its existence entirely unique. "The power of the Unicorn rests in its singularity. Despite variations in the mythology relating to this most elusive and remarkable of creatures, a persistent aspect of unicorn lore is that there is only ever one of them" ([6] p. 583). In Legend, the unicorn senses an attraction to the virgin who is awaiting him with open arms and at the very moment of their reciprocal attraction the unicorn is struck dead by an arrow. This classic representation of the hunting of a unicorn with bait is one of the basic motifs of the perception of the unicorn and its fate. Many representations of the unicorn in iconography demonstrate its death in a fatal, and almost sacred, hunt after its power. Such representations were known throughout England and France from the $13^{\text {th }}$ century until the end of the middle ages in manuscripts such as: The Worksop Bestiary from 1185, Omnibus animantibus from 1220, Harley Bestiary from 1230, Rochester Bestiary from 1230, De avibus or Aviarium by Hugh of Fouilloy (also known by the names of: Hugues de Fouilloy, Hugo Folietanus, Hugo de Fouilloy, Hugues de Fouilloi) from 1250, Bestiaire of Guillaume le Clerc from 1250, De Natura animalium from 1270, Percy Psalter from 1280, Aviarium/Dicta Chrysostomi from 1280, The Ashmole Bestiary from the beginning of the $13^{\text {th }}$ century, Liber de naturis bestiarum from the mid- $13^{\text {th }}$ century, Bestiaire Philippea de Thaona from 1300, Psaltarium Roberti de Ormseby monachi Norwyci... from 1300., The Queen Mary Psalter from 1310, Festal Missal by Petrus de Raimbaucourtand Garnerusa de Morolio from 1323, Bestiaire d'amour/Aesop's Fables by Richard de Fournival from 1325, Bestiarius-Bestiary of Ann Walsh from the $15^{\text {th }}$ century etc. ${ }^{4}$ Many of these bestiaries are compilations of bestiaries and other imaginaria which were already known. It would be quite difficult to make a proper periodisation without categorisation and careful notation. All the manuscripts and bestiaries cited here demonstrate the hunt after the unicorn in which a virgin serves as conscious bait, while soldiers or hunters kill the unicorn with spears, swords, arrows or any other weapon they viewed at the following address: http://bestiary.ca/beasts/beastgallery140.htm\#. 
may have at hand.

Yet Ridley Scott (regarding motif) has added a further modus in which the symbolic value of the films characters can be observed. Namely, besides Jack and Lili, there are hardly any other characters that can be considered human. At the beginning of the film a woman living in a village (something of an Arcadia) with her husband is seen briefly, yet she is almost entirely irrelevant for the films plot. By using subliminal means, Scott encourages the viewer to see Jack and Lili as the only human beings in the entire film. By scaling down humanity in this film to one man and one woman, Scott incorporates the allegory of Adam and Eve, in which Lili breaks the balance once inherent to a perfect world by her wilful desire to touch a unicorn (practically the greatest and most pure being in the forest), and this led to its eventual death and disturbance in the entire balanced order. Allusions to the allegory of Eve are further apparent when the Elf, Gumb, is horrified by the fact that she (a mortal being) had touched a being as perfect as the unicorn and had thus corrupted it. Other apparent Christian elements in the film concern the concept of evil, the definition of sin and its relation to the soul. Christian allegory is made ostensible in the visual perception of Darkness, who is presented as an anthropomorphic devil with animalistic symbols such as hooves and horns. Scott presents ultimate evil as a sexually alluring anthropomorphic being whose symbols are both frightening and magnificent: this makes the biblical allegory of the Fall even more obvious. In order to achieve symbolism pertaining to demonic sexuality, Scott uses the imagery of satyrs and the god Pan, whose representations in classical mythology involved phallic symbols and lascivious scenes of copulation with woodland nymphs. Numerous Grecian vases were painted with images of maenads in fleeing satyrs, spurning them or yielding themselves to them [16]. According to Hesiod, satyrs were lustful and carnal and chased woodland nymphs [17]. When describing Darkness' appearance in the film, Scott uses the visual identity of the satyr: I thought. It better be sexual. Very sexy, this guy. So, it better be a Satyr, half goat. And that was the brief. And he [Rob Bottin] came back with this Idea of red creature with these almost water buffalo horns [12]. The combination of satyr and traditional image of Satan find expression in its goat's legs and horns. Darkness' horns are those of the buffalo and are raised upward, while a satyr's horns are often small and a little longer than its curly hair [17]. There is also something of interest which connects the films Blade Runner and Legend and is not related to the apparition of the unicorn. This is the repeated use of the word satyr when describing the lusts of one of the films characters. Namely, in Blade Runner's screenplay, when describing a scene concerning the relationship between certain protagonists (this scene is not shown in its entirety in the final version of the film), there is a text in which there is a description of how the film's leading actor should perform his desire toward the film's leading female protagonist:

INT. DECKARD'S APARTMENT-BATHROOM-NIGHT70: (...)

Oh, yes. For a moment Deckard stares at her like some furry-legged satyr in rut, the fingers of his other hand rakes through her hair and into the water she 
comes.

\section{INT. DECKARD'S APARTMENT_BEDROOM-MORNING [18]}

It is interesting that of all comparisons a satyr is used, as well as that lust is compared with the boundless lust of the satyr. Darkness' appearance also adds to the Christian allegory that the director incorporates into this film. His half-anima body is identified with symbols of power-the horns and symbols of a satyr-goat's legs. Besides this, he has sharp claws on his fingers which are also an attribute of something animal-like. One of the determinants of evil on the European cultural heritage of the $12^{\text {th }}$ century was the erasure of the clear boundary between the human and the animal which led to an increased fear of sexual intercourse between the two [19]. This is only one of the reasons why the Devil is visualised as half-beast. Although in the Classical period the commingling of the human and animal was allowed in literature, this commingling was considered an absolute error in the medieval imaginarium: any life originating in such was considered an abomination and any sexual intercourse between man and beast was considered one of the worst carnal sins [19]. Darkness in fact embodies the medieval image of the Devil and his very attempt to seduce Lili, who has already succumbed to lust and sin, has the purpose to provoke disgust in the viewer (who has inherited the medieval code regarding disgust).

Darkness is a cross between the motifs of the satyr and Satan. Darkness is never named Satan or the Devil in this film, but this is who he is. As the mediaeval image of Satan is replete with animal symbolism, and as such a perception also exists today, it can be stated with certainty that in this film Darkness represents. The allegory of Satan is clear due to the medieval perception of the Devil which has transformed over time into a myriad of anthropomorphic variants, yet certain symbols always prevailed which determined the appearance of the Devil. These symbols were most often linked to the colour red, horns, infernal flames, sexual lust etc. ([19] p. 27-48).

The concept of developing the allegory of the Fall in this film (in the form of forbidden sexuality) reaches a new level of symbolism with the temptation of the uncorrupted character of Eve. It is as clear how Christian allegory is extended to other parts of this film. For example, the first signs of avarice which slowly overcome Lili when she desires to touch the unicorn (although Jack is against this), transport her to a total adventure of body and soul as she soon finds herself in the underworld in the chambers of the devil himself, in hell. One error and Lili has found herself in the devil's chambers, whose has goal is to conquer her, i.e. to seduce her so that he can subjugate Lili to himself. In order to develop the allegory of the fall, Scott introduces sequences of dialogue in which he ponders the idea on the existence of sin even in one who seems entirely pure: Darkness: Beneath the skin we are already one. Was it not your sin that trapped the Unicorn? Even now, the evil seed of what you've done germinates within you. (...) We are all animals my lady. Most are too afraid to see it! (Legend, 1985)

Besides Lili falling into the trap of lust upon accepting rare gifts in the form of jewels and diamonds, her collapse is made manifest in the scene in which her 
subconscious attired in a black gothic dress dances with her until Lili embraces it and finds herself attired in the same dress. From this moment Lili is no longer naïve and pure: her personality becomes inconstant and wild. Her physical appearance is no longer determined by the beauty of nature but is transformed into a gothic image of a woman with black lipstick. Lili resorts to falsities in the end in order to trick Darkness, with the false pretence that she would like to kill the unicorn herself: in the end she liberates it providing herself and world the chance to start anew. Her atonement begins with this act, yet complete atonement is not achieved as Darkness has not been conquered entirely. At this moment the film presents itself as a morality play.

\section{The Film Legend and the La Dame à la Licorne Tapestry}

The level of iconographic symbolism reaches its climax when Scott's knowledge of the legend of the unicorn and the virgin is taken into consideration, especially when there is also an awareness that symbolic meaning has been provided by the tapestry series La Dame à la licorne. This tapestry series acts almost as an enigma as it consists of six tapestries of which each transmits a message. Each of these tapestries presents one of the bodily senses in code and five senses can be determined: sight, hearing, smell, taste, touch. The sixth sense is almost completely undefined as on the height of the tapestry it is written: $\dot{A}$ Mon Seul Désir, a text which many translate freely as love. Meanwhile, a true solution is difficult to determine due to the complexity of motif and symbol, especially due to the fact that after the word désir there is a hidden letter which cannot be determined. When the relations between and representations of the senses in the Christian tradition of late middle ages are in question, an ambivalent attitude toward them cannot be ignored. Although it is impossible to live without them, the senses (according to the belief of the time) can lead to damnation and moral collapse as people use them in their interactions with one another. One can delight in them, but not to excess as they are symbolic of God's bounty, yet they can also lead one to temptation [20]. Deciphering the mysterious message and the purpose of the allegorical components woven through the five senses, as well as the mysterious message of the sixth tapestry is not the purpose of this work, and seeing that Anne Davenport has written extensively on the tapestry's final message, we will leave the adaptation of the system of senses from the Roman de la Rose aside. ${ }^{5}$

And yet, despite the mystery surrounding the un-deciphered final message, it is interesting to compare the relationship between this tapestry series and Lili in the film Legend as the point of departure is that Ridley Scott was at least informed on this tapestry. As every one of these tapestries presents one of the senses with the virgin as central character, here we will follow this allegory in relation to Lili who has the attributes of the virgin from this tapestry of the legend of the virgin and the unicorn.

${ }^{5}$ More can be read on this theme in Anne Davenport's article: "Is there a Sixth Sense in the Lady and the Unicorn Tapestries?", The New Arcadia Review, vol. 4, Boston Honors Collee Program, 2011.

http://www.bc.edu/publications/newarcadia/archives/4/is_there_a_sixth_sense/, (access 9. 12. 2013.) 
Lili is manifested in this film in several situations and key endeavours. Her attributes and actions determine her as a character and transgressive image of the virgin from the legend of the virgin and unicorn. From her very first appearance she is marked by song, i.e. she sings when she is happy and the motif of song appears in this film on several occasions. As the virgin from the tapestry is a rebus on hearing disclosed by images of playing on an instrument, we can say in Lili's case that her singing represents hearing ( $\left.L^{\prime} O u ̈ i e\right)$. Soon after Lili is introduced, the director sets one of the most mysterious scenes in the entire film: Lili in her friend's cottage is observing a wooden, richly ornamented clock decorated with an image of Death pursuing a maiden. At the moment when her attention has been directed towards this, a new scene is disclosed to Lili which shows the same clock but covered in snow and ice at night. As this is something which will occur in film later, this scene can be interpreted as evidence of Lili's clairvoyance, i.e. her ability to "see" further than other people. This ability is not elaborated further in the film and it s looks as if the scene was unnecessarily inserted. And yet, in this context there is a foundation for such comparisons, as this scene shows that Lili have power of sight, power to see into the future, into another dimension. In the tapestry scene in which there is a representation of the sense of sight ( $L a$ Vue) the virgin is holding a mirror in which the unicorn is reflected. Anna Loba has written on these iconographic representations, placing emphasis on the moral function of the mirror in the encounter between the virgin and unicorn [21]. Yet the allegorical representation of sight is, in fact, characterised by a mirror and not some other object. In a documentary on a first encounter between a member of a tribe from Papua New Guinea and a man from the Western World (directed by Jean Pierre Dutilleux) [22], the members of his tribe are shown several objects, amongst which is a mirror. They were so taken aback and confused by its function that they quickly cover it with tree leaves; when they would look into they would look behind it in order to see what might be behind the image in the mirror. This was like looking into another world and another dimension for them. In the same way, Darkness makes his first appearance to Lili in this film by exiting from a mirror and in this way he makes a passage between two dimensions. Scott's perception and understanding of the mirror as a portal into another dimension can be seen in this.

In Lili's case, the sense of touch (Le Toucher) can be viewed metaphorically only when she touches the unicorn and by doing so practically kills it. The first physical contact with the unicorn also meant its death. This contact is dramatically intensified in this film so its role cannot be ignored. Reference to this fatal contact in later scenes in this film on confirms its importance:

Jack: Oh, god, Gump, she touched him!

Gump: Touched it? A mortal laid hands on a Unicorn? (...) Do you think you can upset the order of the universe and not pay the price? (Legend, 1985)

The sense of smell (L'Odorat) is represented on this tapestry is represented by a wreath woven by the virgin. In the first scene with Lili in this film, she is holding a bouquet of flowers which finally gives to Jack. Also, she is also holding lil- 
ies when Jack shows her the unicorns for the first time.

Taste (Le Goût) on this tapestry is metaphorically represented by a scene in which food is received while the virgin is holding a bird in her left hand. Although Lili actually does hold a bird in her hand in one scene in this film, this motif cannot be directly linked to the aforementioned scene on this tapestry although the bird is colour green as the bird on the tapestry. The motif in the film involving food (as well as taste) has an essential role, and becomes clear in the scene in which Darkness desires to seduce Lili with a dinner which he presents her. She refuses to eat and this act can be seen as the disclosure of a trap in which food has a primary role, and the refusal of food from a being which she despises. It seems as if the tasting of food could lead to an even more unenviable position. The final allegorical motif when researching this tapestry remains undefined, yet is not entirely unknown. On the height of the last tapestry $\dot{A}$ Mon Seul Désir is written, which can be freely translated as My own desire. If we use this translation of the allegory, and if we attempt to transfer it to Lili in this film, her final wish is to live together with Jack. In order to achieve this formal conjugal life with him she provides him with a task: I $m$ a princess. It $s$ my right to set challenge for my suitors. I will marry whoever finds this ring (Legend, 1985) Later in the film, this motif reappears when Jack an Lili no longer face any obstacles to a life together and when Lili experiences a catharsis upon realising the purpose of their conjugal life: I learned something about myself, and something about you. [offering her ring to Jack] So you take that, and you keep it, treasure it. It's part of me. (Legend, 1985). In this symbolic gesture of giving all to love, Lili offers the only piece of jewellery which she had worn at the beginning of the film as a symbol of her will that they be together as one forever. On the $\dot{A} M o n$ Seul Désir tapestry the virgin presents her jewellery in a case which is held by her servant, in this way relinquishing material goods and turning toward what is obviously her one true desire, and according to some it is love. An interpretation also exists that here the tapestry represents the sense of touch a second time, yet most interpreters claim that the final tapestry represents the relinquishing of all earthly material goods [23]. The key to viewing the film Legend perhaps lies in the fact that all the negative things in this film where nothing more than the figments of Lili's dream. After she has awoken, she understands her purpose, gives away all that is material and gives herself up to love. As she had played in her "dream" with the material powers Darkness possesses, it can be said that she has come to understand her real desires thanks to this example. With this decision she has given up herself $\grave{A}$ Mon Seul Désir.

\section{Conclusion}

From all that has been stated, it is evident that Ridley Scott approaches his films with great deliberation and studiousness, and that he does not refrain from incorporating the elements and symbols of a mythic consciousness in order to transmit a message to his viewers through the media of film. The meaning of the 
unicorn's appearance in Blade Runner has a symbolic meaning and represents definite aspects of the personality of the film's main protagonist, the workings of the film's plot and its conclusion. The symbolic value of the unicorn in this film is of even greater significance as the unicorn is represented by Deckard's vision, and Deckard had never encountered a unicorn. In the context of the film's plot, the unicorn is attributed with a meaning which is manifested in symbols of unbound freedom. The physical symbols of the unicorn are classic ones and elaborated according to the visual pattern of the unicorn as it had appeared in heraldry. That is interesting because it shows the visual presentation that Scott intended to show to the widest circle of audience. To make sure everyone has the same visualisation references, he had to show simple, but iconic representation of the unicorn. Chris Lavers in the introduction to his book Natural history of unicorn cites that imagining the unicorn depends on our upbringing background and differs from Christian, secular to New age upbringing ([4] p. 13). The selection of the unicorn is also significant in a symbolic sense as the unicorn conveys several meanings, among which is the unbound freedom which the main protagonist finally achieves, despite the fact that his life was in danger. When mentioning the totemic meaning of the unicorn in this film, mention can be made on the mutual attraction between Deckard, to whom the unicorn becomes a totem, and Rachel, who possesses certain attributes of the sexual purity which the virgin who attracted the unicorn possessed. Certainly, in order that this thesis proves defensible, the character of Gaff needs to be included in the process of the "hunt" as he follows Deckard throughout the film and knows his past.

The film Legend approaches the motif of the unicorn and the virgin in a more direct way, and components which can be linked to medieval perceptions can be observed: the virgin who attracts the attention of the unicorn away from the hunters and soldiers attempting to capture it. Through various levels of symbols which are extended throughout the film, there are definite Christian motifs, and in this way they encompass the idea of the virgin and the unicorn in the context of the Christian perceptions of Western Europe. It is important to emphasise that there is a basis for connecting the character of Lili to the tapestry series $L a$ Dame à la licorne due to the symbolic meanings of individual tapestries. The transgression of motifs is present in both films by this director and is a reflection of the contemporary perception of the symbol of the unicorn in the art of film which is based on the components of motifs found in medieval bestiaries and heraldry. By present such a wide array of symbols and meanings which the unicorn has to offer within the context of levels of motif, it can be stated that the medieval perceptions of the unicorn which Ridley Scott uses inform a part of his artifice as a filmmaker. It is this specific aspect of his artistry which Scott as a director presents as one who is deeply aware of the relationship toward the value of the motifs of medieval perceptions which also have their further existence today in contemporary society. 


\section{References}

[1] Belan, B. (1979) Sintaksa i poetika filma, teorija montaže. svez. 2, Biblioteka Teorija i praksa filma, Zagreb, 11-12.

[2] Peterlić, A. (2000) Osnove teorije filma. Hrvatska sveučilišna naklada, Zagreb, 32.

[3] Sir Ridley Scott Biography, IMDb. http://www.imdb.com/name/nm0000631/bio

[4] Lavers, C. (2010) The Natural History of Unicorn. Harper Perennial, New York. http://www.harpercollins.com/browseinside/index.aspx?isbn13=9780060874148

[5] Ettinghausen, R. (1950) The Unicorn, Freer Gallery of Art Occasional Papers. Vol. 1, No. 3, Smithsonian Institution, Washington DC. https://archive.org/details/unicorn00etti

[6] Matthews, J. and Matthews, C. (2005) The Element Encyclopedia of Magical Creatures: The Ultimate A-Z of Fantastic Beings From Myth and Magic. Harper Element, London, 584.

[7] Coats, J. (1725) A New Dictionary of Heraldry, Explaining the Terms us'd in that Science, with their Etymology, and Different Versions into Latin. Jer. Batley, London, 345. https://archive.org/details/newdictionaryofh00coat

[8] Lauzirika, C. (2007) Director, Dangerous Days: Making Blade Runner. (Documentary). http://www.youtube.com/watch?v=hFKpBsNEzfM

[9] Abbott, A. (2010) Director, on the Edge of Blade Runner. (Documentary) http://www.youtube.com/watch?v=UyWHJ5060L0

[10] Hall, J. (1991) Rječnik tema i simbola u umjetnosti. August Cesarec Zagreb. Zagreb, 317.

[11] Gaijin-San, Shut Up! I Got Words. http://shutupigotwords.wordpress.com/2010/12/29/blade-runner-motifs-and-theme s/

[12] Kenny, J.M. (2002) Director, Creating a Myth the Memories of Legend. https://www.youtube.com/watch?v=G3iBAaljuas

[13] Chevalier, J. and Gheerbrant, A. (2007) Rječnik simbola: Mitovi, snovi, običaji, geste, oblici, likovi, boje, brojevi. Naklada Jesenski i Turk, Zagreb, 245.

[14] Badurina, A. (2006) Leksikon ikonografije liturgike i simbolike zapadnog kršćanstva. Zagreb, 325.

[15] Colin, D. (2004) Rječnik simbola, mitova i legendi. Naklada Ljevak, Zagreb, 195.

[16] Pinsent, J. (1990) Grčka mitologija. Otokar Keršovani, Opatija, 36.

[17] Guirand, F. and Schmidt, J. (2006) Mitovi i mitologija Istorija i rečnik. Plato, Beograd, 214.

[18] Fancher, H. (1980) Blade Runner Script. Brighton Productions Inc. http://www.putlearningfirst.com/br/script.html

[19] Muchembled, R. (2010) Đavao od 12. do 20. stoljeća: Jedna priča. Naklada Pelago, Zagreb, 41.

[20] Synnott, A. (1991) Puzzling over the Senses: From Plato to Marx. In: The Varieties of Sensory Experience: A Sourcebook in the Antropology of Senses, University of Toronto Press, Toronto, Buffalo, London, 69. http://www.udel.edu/History/suisman/611_S05_webpage/hist611_pdfs/Synnott_Pu zzling_over_senses.pdf

[21] Loba, A. (2012) Jednorog u zrcalu, Književna Životinja, Kulturni bestijarij II. 309-322. 
[22] Dutilleux, P. (1976) Director, the Toulambi, First Contact in Ne-Guinea. http://www.youtube.com/watch?v=yHjYxgvnMEE

[23] Nickel, H. (1982) About the Sequence of the Tapestries in the Hunt of the Unicorn and The Lady with the Unicorn. Metropolitan Museum Journal, 17, 9-14. http://www.jstor.org/discover/10.2307/1512782?uid=3738200\&uid=2\&uid=4\&sid=2 1103584692411

https://doi.org/10.2307/1512782

\section{Internet Sources}

1) Blade Runner (IMDb). Available on: http://www.imdb.com/title/tt0083658/

2) Davenport, Anne. 2011. Is there a Sixth Sense in the Lady and the Unicorn Tapestries?

The New Arcadia Review, vol. 4, Boston Honors Collee Program.

http://www.bc.edu/publications/newarcadia/archives/4/is_there_a_sixth_sense/

3) La Dame à la licorne tapestries, museum. Available on: http://www.musee-moyenage.fr/collection/oeuvre/la-dame-a-la-licorne.html

4) Legend (IMDb). Available on: http://www.imdb.com/title/tt0089469/

5) Manuscript archive. Available on: http://bestiary.ca/beasts/beastgallery140.htm

6) Unicorn in heraldry. Available on: http://www.unicorns.co.za/unicorn-lore/heraldry.html 